\title{
Transformational Leadership and Collectivism in Distribution Market: A Study in Central Java - Indonesia
}

\author{
Ahmad MUKHLISIN”, Imam GHOZALI², Indi DJASTUTI ${ }^{3}$ \\ ${ }^{1}$ Ph.D Student at Faculty of Economics and Business, Diponegoro University, Semarang, Indonesia. \\ ${ }^{2,3}$ Faculty of Economics and Business, Diponegoro University, Semarang, Indonesia. \\ Email: mukhlisinahmad27@gmail.com¹, imam.ghozali@live.undip.ac.id², indidjastuti@yahoo.co.id³ \\ * Corresponding Author
}

\author{
Received: 10.09.2021 Accepted: 19.11.2021 Published: 03.12.2021 DOI: 10.47750/QAS/22.185.20
}

\begin{abstract}
This study aims to examine the relationship between transformational leadership and collectivism in Central Java, Indonesia. The survey method of data collection is using structured 150 questionnaires among administrators of Islamic education foundations. Using structural equation modeling (SEM) with the second-order confirmatory factor analysis method, the result indicates that transformational leadership positively and significantly relates to collectivism. The theoretical implication of this study confirms and supports the results of previous studies in the distribution market. While the practical implications of the results of this study are that transformational leadership can be applied in educational organizations as maintaining Javanese cultural values, in this case, collectivist cultures such as the culture of Gotong Royong, often gather where this culture can support the education system. Transformational leadership combined with collectivism can contribute to advancing and developing the education system in Indonesia.
\end{abstract}

Keywords: Transformational leadership, Collectivism, Islamic education foundations

\section{Introduction}

Indonesia is a country that is included in the category of countries whose people have high collectivist values (Riany et al., 2017; Artina et al., 2020). It shows self-interest and family as common interests in a group (Artina et al., 2020). Indonesian people like to do work done together. They are also happy to help each other between them.

In Indonesian culture, it is known as gotong royong, which is doing work together (Slikkerveer, 2019). Gotong royong was traditionally understood as a collective spirit among neighbors to strengthen economic and social resilience (Suwignyo, 2019). It is a traditional value and social capital that regulates the pattern and spirit of life based on trust, openness, mutual care, mutual respect, and hanging together in society's work (Pawane, 2016). Social capital is precious and important in social life (Lukiyanto \& Wijayaningtyas, 2020).

In Javanese culture, there is the term mangan ora mangan seng penting kumpul. This culture emphasizes gathering even though there is no food at all (Kurniati, 2011). With it, harmony is created between them (Supriyadi et al., 2012).

It may be because of this culture of togetherness. Javanese people easily accept leaders who have charisma who can make members feel good and harmonious. Leaders who have a strong vision and mission are seen as charismatic leaders. Leaders who have advantages, especially high intellectuals, are highly respected in Javanese society. Leaders in Java still carry out Javanese principles in carrying out their work (Sarsito, 2006).

In collectivistic cultures, people naturally have a strong attachment to the organization and subordinate individual goals for group goals. Inspirational motivation is easily transmitted to the followers. Intellectual stimulation behavior is more easily facilitated. Likewise, individualized consideration can be more easily facilitated (Jung et al., 1995).

Few researchers have examined the relationship between transformational leadership and collectivist culture in the distribution market. In Indonesia, no research connects transformational leadership with collectivism. This research is important because it determines the relationship between transformational leadership and collectivism, in which Indonesia is a country with a high level of collectivism. Ko (2005) found in his research a positive and significant relationship between transformational leadership and collectivism. Caesar (2016) has indicated a relationship between transformational leadership and collectivist culture in Indonesia, especially in Islamic education foundations.

Practically, the Islamic education foundations in Indonesia have two styles of leadership, such as individual style and collective style. In traditional Islamic education foundations, the leadership model considered is based on heredity. The leadership is determined by kyai or the Islamic education foundation founder. Usually, kyai's children will continue leading if the "big boss" passes away. It shows that the leadership style of traditional Islamic education foundations uses a monarchy system. The continuity of the leadership model creates an exclusive culture in which outsiders cannot take part in the leadership structure. However, the leadership model of modern Islamic education foundations implemented is collective leadership. Collective leadership is implemented as the Islamic 


\section{GENERAL MANAGEMENT}

education foundations have foundations that the leadership seats are transparent and deliberated. Usually, in this Islamic education foundation, the leader is appointed not based on heredity but election democratically. The ones who are considered to lead the Islamic education foundation are chosen in a deliberation. The leader will be chosen by Islamic education foundation administrators that have the characteristics such as honest, belief, communication, and smartness. Besides, they had to have an innovative spirit, be visionary, establish a democratic atmosphere, be ready to be a model, and respect other people's works.

This research is important to understand how transformational leadership characteristics in Islamic education foundations in Indonesia are connected with the collectivity culture inherent in society. In Islamic education, the foundation does not utilize a monarchy system, and it involves deliberation culture to determine the leadership model. The deliberation is as collectivity and democracy will utter a leader that put togetherness forward, innovative, creative, and visionary.

\section{Literature Review and Hypothesis Development}

\subsection{Transformational Leadership}

Leadership is a key factor in organizations (Astuty \& Udin, 2020; Udin, Handayani, Yuniawan, \& Rahardja, 2019). Leadership that inspires subordinates to work optimally, which provides energy and enthusiasm for work, and stimulates intellectuals to solve organizational problems that are transformational leadership (Bass, 1990). Transformational leadership is comprehensive leadership (Tatum et al., 2003) that can overcome all problems.

Transformational leadership has several characteristics (Antonakis et al., 2003; Bass, 1985; Jackson et al., 2013): a) Idealized influence (attributed) refers to the ability to clearly formulate and openly communicate the vision and challenges faced to achieve the goal to followers (Ismail et al., 2011); b) Idealized influence (behavior) refers to charismatic actions of the leader that are centered on values, beliefs, and a sense of mission (Antonakis et al., 2003; Jackson et al., 2013); c) Inspirational motivation refers to the ways leaders energize their followers (Antonakis et al., 2003; Jackson et al., 2013); d) Intellectual stimulation engages followers to look at problems from different perspectives, encourages them to develop innovative strategies (Şahin et al., 2017); and e) Individualized consideration refers to the leader's contribution to follower satisfaction by advising, supporting, and paying attention to the individual needs of followers (Antonakis et al., 2003).

Transformational leadership has a very important role for organizations. It enhances performance (Bass, 1985; Dumdum et al., 2013), innovation (Bass, 1985; Chang, 2016), job satisfaction (Dumdum et al., 2013), and work commitment and effectiveness (Bass, 1999). Therefore, transformational leadership is vital for organizations to succeed (Suhana, Suharnomo, Mas'ud, \& Udin, 2019; Suhana, Udin, Suharnomo, \& Mas'ud, 2019; Sulistiyani, Udin, \& Rahardja, 2018).

\subsection{Transformational Leadership in Education}

In business organizations, educational systems and management and management have management complexities (Anderson, 2017). The leader has a very important role in managing the management complexities in the organization he leads (Fernandez \& Rainey, 2019). Leaders who can overcome the complexities and problems of management can bring the organization to achieve organizational goals and lead the organization towards organizational progress and success (Cranston et al., 2016).

Educational leadership is leadership capable of mobilizing all unsure or elements of an educational organization to achieve educational goals effectively and efficiently (Junaidah, 2016). Transformational leadership provides opportunities and encourages all elements of educational organizations to work hard based on a value system and will take part optimally in achieving organizational goals based on the vision and mission of the organization (Nadur, 2017). In addition, it also emphasizes the importance of the moral role (Jovanovic \& Ciric, 2016) in managing organizations, including educational organizations.

Leadership in an educational context has a clear vision, pays attention to achieving the desired state in the long term, has a clear and structured work program, and is far-sighted (Jovanovic \& Ciric, 2016). Therefore, transformational leadership is suitable for applying in an education setting (Anderson, 2017; Jovanovic \& Ciric, 2016). It is a solution to an ineffective, irrelevant, unfair, and poor-quality education system (Mora, 2012). It has a positive impact in developing educational organizations towards a higher quality (Nadur, 2017).

\subsection{Collectivism}

Collectivism is the extent to which individuals are integrated into a group (Arpaci \& Baloglu, 2016). Individuals with a high level of collectivity will prioritize group interests rather than individual interests (Li et al., 2019). They tend to sacrifice their interests and needs for the sake of their group.

In a collectivistic culture, people are encouraged to share with others (Menard et al., 2018). Collectivism emphasizes that what belongs to one organization member belongs to al organizations (Menard et al., 2018). Happiness and sadness, easy and difficult, were borne together to lighten the burdens they were carrying.

Singelis et al. (1995) divided collectivism into two dimensions, vertical collectivism and horizontal collectivism. Vertical collectivism perceives itself as part of the group and accepts inequality, while horizontal collectivism perceives itself as part of the group by emphasizing equality. Horizontal collectivism reflects that everyone is the same, while vertical collectivism is different.

\subsection{Collectivism in Education}

Walisongo once applied a cultural approach to preaching and teaching religious education (Suparjo, 2008). In his time this cultural approach was very successful and achieved success, so that its impact can still be felt today. The sociocultural conditions in the organization determine the direction of the education policy being carried out to preserve and protect the nation's culture (Yuristia, 2018) so that it is not eroded by other cultures that destroy the nation's characteristics.

In most cases, culture and, in particular, the characteristics associated with individualism and collectivism influence both educators and students (Warchulski, 2019). In a collectivist culture, harmony is very thick in carrying out daily activities, avoiding conflicts. Conflict within the organization can adversely affect organizational achievement (Donkor et al., 2015) if it is mismanaged.

\subsection{Transformational Leadership and Collectivism}

Leadership that emphasizes participation and collaboration in the organization can affect the performance of organizational members (Crede et al., 2019). Organizational problems cannot be resolved alone or can take a long time, so they are inefficient. With collaboration, these problems can be resolved quickly and 


\section{GENERAL MANAGEMENT}

satisfactorily so that they also affect organizational performance. Collectivism puts the interests of groups or organizations ahead of personal interests.

According to Terry (Mora, 2012), transformational leadership is an activity to influence people so that they like to try to achieve group goals. According to Ordway Teod in his book "The Art Of Leadership" (Tead, 1935) is the activity of influencing people to work together to achieve the goals they want. Young in Kartono (1998) defines that leadership as domination based on personal abilities that can encourage or invite others to do something, based on acceptance or acceptance by the group, and have special skills appropriate for special situations.

The essence of transformative leadership is to turn potential into real energy, transforming the institutional potential for energy to improve learning processes and outcomes (Shields et al., 2017). So, principal leadership can be defined as a form (style) that influences subordinates comprising of teachers, administrative staff, students, and parents of students (Sebastian \& Allensworth, 2012).

The concept of transformational leadership was first put forward by James McGregor Burns (Hansbrough \& Schyns, 2018). Concerning transformational leadership, Bernard Bass (Gregory Stone et al., 2004) says: "Transformational leaders transform the personal values of followers to support the vision and goals of the organization by fostering an environment where relationships can be formed and by establishing a climate of trust in which visions can be shared."

The relationship between transformational leadership and performance is particularly strong in countries with high levels of collectivism (Crede et al., 2019). Collectivism could positively moderate the relationship between transformational leadership and affective commitment (Newman \& Butler, 2014). Caesar (2016) indicates that there is a relationship between transformational leadership and collectivism. Ko (2005) found that transformational leadership is positively and significantly related to collectivism. Jung and Avolio (1999) state that transformational leadership in a collectivistic culture generates many ideas.

Collectivist values are needed in the work environment (Liu et al., 2016). Tasks that are interrelated among members in a workgroup require members to act collectively (Yidong \& Xinxin, 2013). Without this attitude, members of the organization will only care about the individual tasks they handle without considering that their work will be a product for colleagues in the work process (Costa et al., 2014).

Collective values are in line with universal values (Rabinovich et al., 2012). The attitude of helping, helping, solidarity, togetherness, and tolerance are examples of collective values needed in the work environment (FischerPreßler et al., 2019). Its existence tends to positively affect members of the organization, especially in maintaining interpersonal relationships between members. Therefore, these values will have an actual effect when they have become applicable values and become the life force of the organization or have become the culture within the organization (Boniface, 2011). For that, we need a powerful leader who can create an existing culture based on collective values (Warrick, 2017). Thus,

$\mathrm{H} 1$ : There is a positive relationship between transformational leadership and collectivism

\section{Research Methods}

The population of this study is the administrator of Islamic education foundations spread across Central Java at 3719. The sampling technique used in this study was proportional. The selected research samples were Surakarta city, Klaten district, Pati district, Kudus district, Banyumas district, Cilacap district, Magelang district, Wonosobo district, Semarang city, Demak district, Pekalongan city, and Tegal city. These areas are in Central Java, Indonesia, with the largest number of Islamic education foundations. Questionnaires are given to the Islamic education foundation administrators who know the leadership style and are involved in organizational activities. The data collection method used in this study was the distribution of questionnaires via social media with the WhatsApp application because it is impossible to meet directly with respondents because of the coronavirus 19 pandemic, which is entering a critical period. There are 150 questionnaires collected. Respondents answered research questions by sending them via the google form application. The distribution and collection of questionnaires were carried out for 3 months (JulySeptember 2020).

This study's respondents' descriptions are: 133 (89\%) were male respondents, while $17(11 \%)$ were women. Respondents aged 21-30 years were 12 (8\%), aged $31-40$ years were 64 $(42.7 \%)$, aged $41-50$ years were 51 (34\%), aged 50 years and over were $23(15.3 \%)$. Education level of respondents: 13 respondents $(8.7 \%)$ have a high school education, and below, 83 respondents (55.3\%) have a bachelor's degree, 48 respondents (32\%) have a master's degree, and 6 respondents (4\%) have a doctoral education.

The research instrument in this study used closed questions addressed to respondents. 33 question items were used, 23 questions for transformational leadership and 10 questions for collectivism. The questionnaires help gather attitudes, opinions, behavior, facts, and other information (Donkor et al., 2021). All questionnaire items are based on a five-level Likert scale ranging from 1 to 5 . 1 indicates disagreement, and 5 indicates agreement.

Transformational leadership consists of 5 dimensions, the influence of idealistic attributes (IIA) (4 items), the influence of idealistic behavior (IIB) (4 items), intellectual stimulation (IS) (5 items), inspirational motivation (IM) (5 items), and individual consideration (IC) (5 items). Question items were developed from Al-husseini and Elbeltagi (2018) and Chaoping and Kan (2008). Sample items include "The leader talks optimistically about the future" and "The leader talks about important values."

Collectivism consists of two dimensions, horizontal $(H)(5$ items) and vertical (V) (5 items). The question items were developed from Noordin and Jusoff (2010). Sample items include "If a co-worker gets a prize, I would feel proud" and "I like sharing little things."

The hypothetical model in this study is a correlation model which assumes "a linking between transformational leadership and collectivism. Structural equation modeling (SEM) was used to examine the construction of the questionnaire. The secondorder confirmatory factor analysis technique was used to analyze the relationship between transformational leadership and collectivism. 


\section{GENERAL MANAGEMENT}

\begin{tabular}{|c|c|c|}
\hline Construct (Dimension) & Indicator & Loading Factor \\
\hline \multicolumn{3}{|l|}{ Transformational Leadership } \\
\hline \multirow[t]{4}{*}{ Idealized Influence Attributed (IIA) } & IIA1(Instill Pride) & 0.775 \\
\hline & IIA2 (Goes Beyond Self-Interest) & 0.814 \\
\hline & \begin{tabular}{|l|l} 
IIA3 (Build Honor) \\
\end{tabular} & 0.872 \\
\hline & IIA4 (Self-Confidence) & 0.852 \\
\hline \multirow[t]{4}{*}{ Idealized Influence Behavior (IIB) } & IIB1 (Talk About Value) & 0.823 \\
\hline & IIB2 (Have Strong Goals) & 0.772 \\
\hline & IIB3 (Consider Moral) & 0.792 \\
\hline & IIB4 (Have a Mission) & 0.815 \\
\hline \multirow{5}{*}{$\begin{array}{l}\text { Intellectual Stimulation (IS) } \\
\backslash\end{array}$} & IS1 (Evaluating Suggestions and Ideas) & 0.828 \\
\hline & IS2 (Looking for Different Perspective) & 0.820 \\
\hline & IS3 (Suggest New Way) & 0.689 \\
\hline & IS4 (Encourage New Ideas) & 0.808 \\
\hline & IS5 (Open Minded) & 0.207 \\
\hline \multirow[t]{5}{*}{ Inspirational Motivation (IM) } & IM1 (Optimistic Future) & 0.869 \\
\hline & IM2 (Enthusiastic about Achievement) & 0.806 \\
\hline & IM3 (Compelling Vision) & 0.864 \\
\hline & IM4 (Confident that Goals will be achieved) & 0.835 \\
\hline & IM5 (Develop Passion) & 0.839 \\
\hline \multirow[t]{5}{*}{ Individualized Consideration (IC) } & IC1 (Provide Training) & 0.246 \\
\hline & IC2 (Take a Personal Approach) & 0.321 \\
\hline & IC3 (Assume different everyone) & 0.833 \\
\hline & IC4 (Develop Talent) & 0.808 \\
\hline & IC5 (Helping Trouble) & 0.685 \\
\hline \multicolumn{3}{|l|}{ Collectivism } \\
\hline \multirow[t]{5}{*}{ Horizontal $(\mathrm{H})$} & H1 (Happy that friends get gifts) & 0.833 \\
\hline & H2 (Help from Adversity) & 0.810 \\
\hline & H3 (Maintaining Harmony) & 0.850 \\
\hline & H4 (Like to share) & 0.837 \\
\hline & H5 (Happy to work together) & 0.836 \\
\hline \multirow[t]{5}{*}{ Vertical } & V1 (Sacrifice for the sake of the family) & 0.846 \\
\hline & V2 (Make Family Happy) & 0.836 \\
\hline & V3 (Consult) & 0.892 \\
\hline & \begin{tabular}{|l|} 
V4 (Duty before pleasure) \\
\end{tabular} & 0.862 \\
\hline & V5 (Tendency to agree) & 0.864 \\
\hline
\end{tabular}

Table 1: Loading factor

The loading factor in table 1 shows that several indicators are not valid. The IS 5 (Open Minded) indicator from the intellectual stimulation dimension with a loading factor value of 0.207 is less than the critical loading factor value of 0.50 so that the IS 5 (Open Minded) indicator is invalid. The IC1 (Provide Training) indicator with a loading factor value of 0.246 and the IC2 (Take a Personal Approach) indicator with a loading factor value of 0.321 from the dimensions of individual considerations is invalid because it is less than 0.50 . These indicators have not been able to form latent variables so that the estimation of the research model is carried out again by removing these indicators.

\section{Results}

The results of this study were processed using AMOS 24.0. The result of second-order CFA showed that the fit indices suggest that the model fits. CMIN/DF with 1.147, TLI with 0.981 , CFI with 0.983 , and RMSEA with 0.030 , all of them were fit. GFI with 0.842 and AGFI with 0.814 , both of them close to fit. Overall, the fit indices suggest that the model fits. 


\section{GENERAL MANAGEMENT}

\begin{tabular}{|c|c|c|c|c|}
\hline Construct/ Dimension & Indicator & $\begin{array}{l}\text { Loading } \\
\text { Factor }\end{array}$ & \begin{tabular}{|l|} 
Variance \\
Extracted
\end{tabular} & $\begin{array}{l}\text { Construct } \\
\text { Reliability }\end{array}$ \\
\hline \multicolumn{5}{|l|}{ Transformational Leadership } \\
\hline \multirow{4}{*}{$\begin{array}{lll}\begin{array}{l}\text { Idealized } \\
\text { (IIA) }\end{array} & \text { Influence } & \text { Attributed } \\
\end{array}$} & IIA1(Instill Pride) & 0.775 & \multirow[t]{4}{*}{0.796} & \multirow[t]{4}{*}{0.940} \\
\hline & IIA2 (Goes Beyond Self-Interest) & 0.814 & & \\
\hline & IIA3 (Build Honor) & 0.872 & & \\
\hline & IIA4 (Self-Confidence) & 0.852 & & \\
\hline \multirow[t]{4}{*}{ Idealized Influence Behavior (IIB) } & IIB1 (Talk About Value) & 0.823 & \multirow[t]{4}{*}{0.780} & \multirow[t]{4}{*}{0.934} \\
\hline & IIB2 (Have Strong Goals) & 0.772 & & \\
\hline & IIB3 (Consider Moral) & 0.792 & & \\
\hline & IIB4 (Have a Mission) & 0.815 & & \\
\hline \multirow[t]{4}{*}{ Intellectual Stimulation (IS) } & $\begin{array}{l}\text { IS1 (Evaluating Suggestions and } \\
\text { Ideas) }\end{array}$ & 0.826 & \multirow[t]{4}{*}{0.792} & \multirow[t]{4}{*}{0.938} \\
\hline & \begin{tabular}{|llll} 
IS2 & (Looking & for & Different \\
Perspective) & & \\
\end{tabular} & 0.819 & & \\
\hline & IS3 (Suggest New Way) & 0.693 & & \\
\hline & IS4 (Encourage New Ideas) & 0.808 & & \\
\hline \multirow[t]{5}{*}{ Inspirational Motivation (IM) } & IIM1 (Optimistic Future) & 0.869 & \multirow[t]{5}{*}{0.793} & \multirow[t]{5}{*}{0.950} \\
\hline & \begin{tabular}{|lll} 
IM2 & (Enthusiastic & about \\
Achievement) & & \\
\end{tabular} & 0.806 & & \\
\hline & IM3 (Compelling Vision) & 0.864 & & \\
\hline & $\begin{array}{l}\text { IM4 (Confident that Goals will be } \\
\text { achieved) }\end{array}$ & 0.835 & & \\
\hline & IM5 (Develop Passion) & 0.839 & & \\
\hline \multirow[t]{3}{*}{ Individualized Consideration (IC) } & IC3 (Assume different everyone) & 0.811 & \multirow[t]{3}{*}{0.791} & \multirow[t]{3}{*}{0.919} \\
\hline & IC4 (Develop Talent) & 0.839 & & \\
\hline & IC5 (Helping Trouble) & 0.686 & & \\
\hline \multicolumn{5}{|l|}{ Collectivism } \\
\hline \multirow{5}{*}{ Horizontal $(\mathrm{H})$} & $\mathrm{H} 1$ (Happy that friends get gifts) & 0.833 & \multirow[t]{5}{*}{0.779} & \multirow[t]{5}{*}{0.946} \\
\hline & H2 (Help from Adversity) & 0.810 & & \\
\hline & H3 (Maintaining Harmony) & 0.850 & & \\
\hline & H4 (Like to share) & 0.837 & & \\
\hline & H5 (Happy to work together) & 0.836 & & \\
\hline \multirow[t]{5}{*}{ Vertical (V) } & $\begin{array}{l}\text { V1 (Sacrifice for the sake of the } \\
\text { family) }\end{array}$ & 0.846 & \multirow[t]{5}{*}{0.801} & \multirow[t]{5}{*}{0.953} \\
\hline & V2 (Make Family Happy) & 0.836 & & \\
\hline & V3 (Consult) & 0.892 & & \\
\hline & V4 (Duty before pleasure) & 0.862 & & \\
\hline & V5 (Tendency to agree) & 0.864 & & \\
\hline
\end{tabular}

Table 2: Reliability of construct

The results of Variance Extracted and Construct Reliability calculation show that the construct is valid and reliable. This is indicated by the Variance Extracted and Construct Reliability values that are more than the required criteria, over 0.70 or over 0.50 . Variance extracted values above 0.50 indicate good convergence so that the validity of the latent construct can be interpreted as valid. The value of construct reliability above 0.70 indicates that the latent construct has reliable. Thus, it can be concluded that transformational leadership and collectivism constructs have met the required requirements. This means that the indicators that make up the variable are able or valid to explain the existing constructs.

\begin{tabular}{|l|l|l|l|l|l|}
\hline & Correlation & Estimate & S.E & C.R & P \\
\hline Transformational Leadership $\rightarrow$ Collectivism & 1.091 & 0.338 & 0.052 & 6.508 & 0.000 \\
\hline
\end{tabular}

Table 3: Hypothesis testing

Table 3 indicated that the hypothesis was supported that transformational leadership relates to collectivism. The correlations estimate the correlation between transformational leadership and collectivism was 1.091 with an estimated value of 0.338 , S.E value of 0.052 , and C.R value of 6.508 . C. R stands for a critical ratio which is obtained from the estimated value (0.338) divided by the standard error value (S.E) (0.052). Critical values that are outside the range of -1.96 to 1.96 
produce a significant $p$-value. The relationship between transformational leadership and collectivism with a C.R value of 6.508 is outside the range of -1.96 to 1.96 so that the relationship produces a significant $p$-value. The correlation between transformational leadership and collectivism was positive and significant, with a significance value of 0.000 . The correlation value of the relationship between transformational leadership and collectivism is 1.091, indicating a positive and strong direction of the relationship.

\section{Discussion}

The hypothesis expects that transformational leadership is related to collectivism (Miao et al., 2012). This hypothesis was supported empirically. This study supported the hypothesis that there is a positive relationship between transformational leadership and collectivism (Sheikh et al., 2013). Leaders who instill pride in their followers, transcend self-interest, build respect, and are full of confidence can be applied to a culture of collectivism (Karakitapoğlu-Aygün \& Gumusluoglu, 2013). They can convey values related to the vision and mission of the organization in a society that has a high collectivism culture (Gochhayat et al., 2017). Transformational leaders consider moral aspects (Ciric \& Jovanovic, 2016) following Indonesian culture, known for its high moral aspects.

Transformational leaders pay attention to suggestions and ideas and are open to new ideas that develop in the organizational environment (Al-Husseini \& Elbeltagi, 2016). Following the fourth principle of Pancasila, which reads society led by wisdom in representative deliberations, Indonesian people uphold the values of deliberation in all aspects (Taufiq et al., 2016). When facing problems or difficulties, they are discussed together to find solutions to these problems. This is also applied in educational organizations; leaders solve problems related to education by deliberating together (Raelin, 2012).

Transformational leaders provide motivation and inspiration by conveying a vision of the future with confidence, being optimistic about the future, confident about achieving goals, and developing enthusiasm for the organization, always working seriously and working creatively (Dust et al., 2014). In collectivist cultures, people tend to enjoy working together. By working together, they will have the confidence to work easily and quickly. Transformational leaders pay attention to the circumstances and conditions of their followers, help develop the strengths of their followers, and help the difficulties experienced by their followers. In a culture of collectivism, there is a strong emphasis on togetherness and mutual care. If there are difficulties or problems, the others help find solutions (Giddens, 2018).

Transformational leadership can be applied in educational organizations such as Islamic education foundations. Education systems and management have complex problems that are relatively similar to those in business organizations (Anderson, 2017). Transformational leadership is very suitable for applied in an educational setting (Anderson, 2017; Jovanovic \& Ciric, 2016). It is very suitable to be applied by foundation leaders and by teachers in leading their students (Andriani et al., 2018). The result of this study is consistent with previous studies. Ko et al. (2018) has stated that transformational leadership is positively and significantly related to collectivism. Collectivism combined with transformational leadership will result in high performance (Jung \& Avolio, 1999)

This study follows the number of modern Islamic boarding schools in Central Java that put forward the principles of deliberation and democracy in choosing leaders. The results have an impact on the performance of an organization that continues to grow and develop. Islamic boarding schools need a transformational leader to adapt to the times and globalization in preparing superior and competitive students. These results can be considered for traditional Islamic boarding schools that still utilize the modal system in choosing their leaders. Leaders based on descent still rely on charisma, authoritarian, and oldfashioned systems that affect organizational development stagnation.

The collectivistic culture is inherent in Javanese society. Javanese people are happy to be together. When getting a gift, Javanese people gather to celebrate it. When having trouble, Javanese people gather to feel their concern together. Even when they want to travel, Javanese people gather to pray for safety.

The relationship between transformational leadership and collectivism can be explained as follows. With togetherness, leaders will easily convey their vision and mission, motivate, provide intellectual stimulation, and pay attention to their followers.

The transformational leadership style focuses on deliberation procedures in terms of decision-making (Kwan, 2020). Transformational leaders will involve other people in many important decisions taken (Celik et al., 2016). The goal is that the agreements taken are based on mutual consensus, and the benefits can be felt widely. In implementing the leadership system, traditional Islamic educational foundations are held by one or two Kyai, who are usually descendants of the founders of the pesantren concerned. Compared to traditional Islamic educational foundations, modern Islamic educational foundations are more likely to use a consensus leadership style by opening up opportunities for competent people, even though they do not come from the descendants of the founders of the Islamic educational foundation. Competent leaders will certainly produce democratic and beneficial decisions for many people (Hallo et al., 2020). Such leadership style can be easily found in modern Islamic educational foundations.

\section{Conclusion}

The result of this study concluded that transformational leadership was positively and significantly related to collectivism. Transformational leadership can be applied in an organization where the collectivist culture is high. Indonesia is a country with a high level of collectivism, and transformational leadership is suitable for organizations in Indonesia, including educational organizations (Anderson, 2017; Jovanovic \& Ciric, 2016).

The results of this study have theoretical implications as well as practical implications in the distribution market. The theoretical implication of this study confirms and supports the study results from Caesar (2016) and Ko (2005). While the practical implication of the results of this study is that transformational leadership can be applied in educational organizations while maintaining the values of Javanese culture, in this case, collectivist culture such as the culture of cooperation (Gotong Royong), often gathering where this culture can sustain the education system. Transformational leadership, combined with collectivism, can contribute to promoting and developing the education system in Indonesia. Foundation leaders and teachers can apply a transformational leadership style in dealing with and managing educational problems in their activities.

The limitation of this study is that the research sample is not large enough, namely 150, resulting in the results of the goodness of fit. Some are not fit. Kline (2014) recommends a minimum SEM sample of 200 to reduce bias in model estimation. In addition, the research is still limited to one 
province, namely Central Java, so it does not represent the whole of Indonesia. Another limitation of this study is that this result relates transformational leadership with five dimensions and several indicators with collectivist culture with two dimensions with five indicators for each.

Recommendations for future research include expanding the research object by targeting all forms of organization in Indonesia, such as religious organizations. In future research, it is necessary to develop a research model by connecting transformational leadership and collectivism by connecting each dimension of transformational leadership with each dimension of collectivist culture, such as the idealized influence attributed dimension related to the horizontal dimension, the idealized influence behavior dimension related to the horizontal, the intellectual stimulation dimension related to the horizontal dimension, the inspirational motivation dimension related to the horizontal dimension, and the individual consideration related to horizontal, and each transformational leadership dimension related to vertical collectivism.

\section{References}

[1] Al-Husseini, S., \& Elbeltagi, I. (2016). Transformational leadership and innovation: a comparison study between Iraq's public and private higher education. Studies in Higher Education. https://doi.org/10.1080/03075079.2014.927848

[2] Anderson, M. (2017). Transformational Leadership in Education: A Review of Existing Literature. International Social Science Review.

[3] Andriani, S., Kesumawati, N., \& Kristiawan, M. (2018). The influence of transformational leadership and work motivation on teacher's performance. International Journal of Scientific and Technology Research.

[4] Antonakis, J., Avolio, B. J., \& Sivasubramaniam, N. (2003). Context and leadership: an examination of the nine-factor fullrange leadership theory using the Multifactor Leadership Questionnaire. The Leadership Quarterly, 14(3), 261-295. doi:10.1016/s1048-9843(03)00030-4

[5] Arpaci, I., \& Baloğlu, M. (2016). The impact of cultural collectivism on knowledge sharing among information technology majoring undergraduates. Computers in Human Behavior, 56, 65-71. doi:10.1016/j.chb.2015.11.031

[6] Artina, B. S., Desnasari, D., Fitriyah, F., \& Rizkita, R. G. (2020). The Workforce in Indonesian Organizations: An Analysis Based Upon the Cultural Dimensions of Hofstede's Model. Journal of International Conference Proceedings, 3(1), 56-64. doi:10.32535/jicp.v2i4.780

[7] Bass, B. M. (1985). Leadership: Good, better, best. Organizational Dynamics, 13(3), 26-40. doi:10.1016/00902616(85)90028-2

[8] Bass, B. M. (1990). From transactional to transformational leadership: Learning to share the vision. Organizational Dynamics, 18(3), 19-31. doi:10.1016/0090-2616(90)90061-s

[9] Bass, B. M. (1999). Current developments in transformational leadership: Research and applications. The PsychologistManager Journal, 3(1), 5-21. doi:10.1037/h0095852

[10] Boniface, C. M. (2011). Organizational culture as a driver of competitive advantage. Journal of Academic \& Business Ethics.

[11] Caesar, L. A. Y. (2016). Performance Excellence by Transformational Leadership in Developing Collectivistic Culture for Indonesian Companies. Pertanika J. Soc. Sci. \& Hum, 24, $19-32$.

[12] CELIK, A., AKGEMCI, T., \& AKYAZI, T. E. (2016). A Comparison between the Styles of Transformational Leaders and Authentic Leaders in Crisis Management. International
Journal of Academic Research in Business and Social Sciences, 6(2). doi:10.6007/ijarbss/v6-i2/2023

[13] Chang, Y.-Y. (2016). Multilevel transformational leadership and management innovation. Leadership \& Organization Development Journal, 37(2), 265-288. doi:10.1108/lodj-062014-0111

[14] Ciric, M., \& Jovanovic, D. (2016). Student Engagement as a Multidimensional Concept. doi:10.15405/epsbs.2016.09.24

[15] Costa, P. L., Passos, A. M., \& Bakker, A. B. (2014). Team work engagement: A model of emergence. Journal of Occupational and Organizational Psychology, 87(2), 414-436. doi:10.1111/joop.12057

[16] Cranston, N., Watson, J., Allen, J., Wright, S., Hay, I., Beswick, K., Smith, C., Roberts, W., \& Kameniar, B. (2016). Overcoming the Challenges of Keeping Young People in Education: A wicked problem with implications for leadership, policy and practice. Leading \& Managing.

[17] Crede, M., Jong, J., \& Harms, P. (2019). The generalizability of transformational leadership across cultures: a meta-analysis. Journal of Managerial Psychology, 34(3), 139-155. doi:10.1108/jmp-11-2018-0506

[18] Donkor, F., Dongmei, Z., \& Sekyere, I. (2021). The Mediating Effects of Organizational Commitment on Leadership Styles and Employee Performance in SOEs in Ghana: A Structural Equation Modeling Analysis. SAGE Open, 11(2), 215824402110088. doi:10.1177/21582440211008894

[19] Donkor, P., Afriyie, S., AdjeiDanquah, B., \& WilsonKwakuNimsah. (2015). Effect of Conflict on Employees Performance: Evidence from Coca Cola Company Limited, Kumasi Branch. Merican Scientific Research Journal for Engineering, Technology, and Sciences (ASRJETS), 14(3), 44-53.

[20] Dumdum, U. R., Lowe, K. B., \& Avolio, B. J. (2013). A MetaAnalysis of Transformational and Transactional Leadership Correlates of Effectiveness and Satisfaction: An Update and Extension. Monographs in Leadership and Management, 3970. doi:10.1108/s1479-357120130000005008

[21] Dust, S. B., Resick, C. J., \& Mawritz, M. B. (2013). Transformational leadership, psychological empowerment, and the moderating role of mechanistic-organic contexts. Journal of Organizational Behavior, 35(3), 413-433. doi:10.1002/job.1904

[22] Fernandez, S., \& Rainey, H. G. (2017). Managing Successful Organizational Change in the Public Sector*. Debating Public Administration, 7-26. doi:10.4324/9781315095097-2

[23] Fischer-Preßler, D., Schwemmer, C., \& Fischbach, K. (2019). Collective sense-making in times of crisis: Connecting terror management theory with Twitter user reactions to the Berlin terrorist attack. Computers in Human Behavior, 100, 138-151. doi:10.1016/j.chb.2019.05.012

[24] Giddens, J. (2018). Transformational leadership: What every nursing dean should know. Journal of Professional Nursing, 34(2), 117-121. doi:10.1016/j.profnurs.2017.10.004

[25] Gochhayat, J., Giri, V. N., \& Suar, D. (2017). Influence of Organizational Culture on Organizational Effectiveness: The Mediating Role of Organizational Communication. Global Business Review, 18(3), 691-702. doi:10.1177/0972150917692185

[26] Gregory Stone, A., Russell, R. F., \& Patterson, K. (2004). Transformational versus servant leadership: a difference in leader focus. Leadership \& Organization Development Journal, 25(4), 349-361. doi:10.1108/01437730410538671

[27] Hallo, L., Nguyen, T., Gorod, A., \& Tran, P. (2020). Effectiveness of Leadership Decision-Making in Complex Systems. Systems, 8(1), 5. doi:10.3390/systems 8010005

[28] Hansbrough, T. K., \& Schyns, B. (2018). The Appeal of Transformational Leadership. Journal of Leadership Studies, 
12(3), 19-32. doi:10.1002/jls.21571

[29] Ismail, A., Hasan Al-Banna Mohamed, Sulaiman, A. Z., Mohamad, M. H., \& Yusuf, M. H. (2011). An Empirical Study of the Relationship between Transformational Leadership, Empowerment and Organizational Commitment. Business and Economics Research Journal, 2(1).

[30] Jackson, T. A., Meyer, J. P., \& Wang, X.-H. (Frank). (2012). Leadership, Commitment, and Culture. Journal of Leadership \& Organizational Studies, 20(1), 84-106. doi:10.1177/1548051812466919

[31] Jovanovic, D., \& Ciric, M. (2016). Benefits of Transformational Leadership in the Context of Education. doi:10.15405/epsbs.2016.09.64

[32] Junaidah, J. (2016). Kepemimpinan Transformasional dalam Pendidikan [Transformational Leadership in Education]. AlIdaroh Jurnal Kependidikan Islam [AI-Idaroh Journal of Islamic Education], 6(2).

[33] Jung, D. I., \& Avolio, B. J. (1999). Effects of Leadership Style and Followers' Cultural Orientation on Performance in Group and Individual Task Conditions. The Academy of Management Journal, 42(2), 208-218.

[34] Jung, D. I., Bass, B. M., \& Sosik, J. J. (1995). Bridging Leadership and Culture: A Theoretical Consideration of Transformational Leadership and Collectivistic Cultures. Journal of Leadership Studies, 2(4), 3-18. doi:10.1177/107179199500200402

[35] Karakitapoğlu-Aygün, Z., \& Gumusluoglu, L. (2013). The bright and dark sides of leadership: Transformational vs. nontransformational leadership in a non-Western context. Leadership, 9(1), 107-133. doi:10.1177/1742715012455131

[36] Kartono, K. (1998). Pemimpin dan Kepemimpinan Dalam Organisasi. Raja Grafindo Persada.

[37] Kline, R. B. (n.d.). Convergence of Structural Equation Modeling and Multilevel Modeling. The SAGE Handbook of Innovation in Social Research Methods, 562-589. doi:10.4135/9781446268261.n31

[38] Ko, C., Ma, J., Bartnik, R., Haney, M. H., \& Kang, M. (2017). Ethical Leadership: An Integrative Review and Future Research Agenda. Ethics \& Behavior, 28(2), 104-132. doi:10.1080/10508422.2017.1318069

[39] Ko, J. (2005). Impact of Leadership and Team Members' Individualism-Collectivism on Team Processes and Outcomes: A Leader-Member Exchange Perspective. The University of Arizona.

[40] Kurniati, N. M. T. (2011). Subjective Well Being in Javanese Collectivistic Culture. In C. S. Handayani \& M. E. Madyaningrum (Eds.), International Conference of Revisited Asian Society "Exploration of Asian Indigenous Perspective: Communalities and Differences."

[41] Kwan, P. (2019). Is Transformational Leadership Theory Passé? Revisiting the Integrative Effect of Instructional Leadership and Transformational Leadership on Student Outcomes. Educational Administration Quarterly, 56(2), 321349. doi:10.1177/0013161×19861137

[42] Li, K.-K., Chan, M. W. H., Lee, S. S., \& Kwok, K. O. (2019). The mediating roles of social benefits and social influence on the relationships between collectivism, power distance, and influenza vaccination among Hong Kong nurses: A crosssectional study. International Journal of Nursing Studies, 99, 103359. doi:10.1016/j.jinurstu.2019.05.007

[43] Liu, L. ., Du, R., \& Ai, S. Z. (2016). Impact of Culture on the Relationship between Knowledge Sharing and Innovative Behavior in IT Services Industry. Chinese Journal of Management Science.

[44] Lukiyanto, K., \& Wijayaningtyas, M. (2020). Gotong Royong as social capital to overcome micro and small enterprises' capital difficulties. Heliyon, 6.
[45] Menard, P., Warkentin, M., \& Lowry, P. B. (2018). The impact of collectivism and psychological ownership on protection motivation: A cross-cultural examination. Computers \& Security, 75, 147-166. doi:10.1016/j.cose.2018.01.020

[46] Miao, Q., Newman, A., \& Lamb, P. (2012). Transformationa leadership and the work outcomes of Chinese migrant workers: The mediating effects of identification with leader. Leadership, 8(4), 377-395. doi:10.1177/1742715012444055

[47] Mora, C. (2012). Transformational Leadership in Education: Concept Analysis. Transylvanian Review of Administrative Sciences, Special Issue, 184-192.

[48] Nadur, E. S. (2017). Implementasi Kepemimpinan Transformasional Kepala Sekolah dalam Membentuk Budaya Sekolah dalam Kontek Pendidikan di Indonesia [Implementation of Principal Transformational Leadership in Shaping School Culture in the Context of Education in Indonesia]. Jurnal Penelitian [Research Journal], 21(1), 48-61.

[49] Newman, A., \& Butler, C. (2013). The influence of follower cultural orientation on attitudinal responses towards transformational leadership: evidence from the Chinese hospitality industry. The International Journal of Human Resource Management, 25(7), 1024-1045. doi:10.1080/09585192.2013.815250

[50] Pawane, F. S. (2016). Fungsi Pomabari (Gotong Royong) Petani Kelapa Kopra di Desa Wasilio Kecamatan Maba Utara Kabupaten Halmahera Timur Provinsi Maluku Utara [The Function of Pomabari (Gotong Royong) for Copra Coconut Farmers in Wasilio Village, North Maba District, East Halm. Jurnal Holistik [Holistic Journal], 18.

[51] Rabinovich, A., Morton, T. A., Postmes, T., \& Verplanken, B. (2011). Collective self and individual choice: The effects of inter-group comparative context on environmental values and behaviour. British Journal of Social Psychology, 51(4), 551569. doi:10.1111/j.2044-8309.2011.02022.x

[52] Raelin, J. A. (2012). Dialogue and deliberation as expressions of democratic leadership in participatory organizational change. Journal of Organizational Change Management, 25(1), 7-23. doi:10.1108/09534811211199574

[53] Riany, Y. E., Meredith, P., \& Cuskelly, M. (2016) Understanding the Influence of Traditional Cultural Values on Indonesian Parenting. Marriage \& Family Review, 53(3), 207226. doi:10.1080/01494929.2016.1157561

[54] Şahin, F., Gürbüz, S., \& Şeşen, H. (2017). Leaders' managerial assumptions and transformational leadership: the moderating role of gender. Leadership \& Organization Development Journal, 38(1), 105-125. doi:10.1108/lodj-11-2015-0239

[55] Sarsito, T. (2006). Javanese culture as the source of legitimacy for Soeharto's government. Asia Europe Journal, 4(3), 447461. doi:10.1007/s10308-006-0078-y

[56] Sebastian, J., \& Allensworth, E. (2012). The Influence of Principal Leadership on Classroom Instruction and Student Learning: A Study of Mediated Pathways to Learning. Educational Administration Quarterly. https://doi.org/10.1177/0013161X11436273

[57] Sheikh, A. Z., Newman, A., \& Al Azzeh, S. A.-F. (2013). Transformational leadership and job involvement in the Middle East: the moderating role of individually held cultural values. The International Journal of Human Resource Management, 24(6), 1077-1095. doi:10.1080/09585192.2012.703216

[58] Shields, C., Dollarhide, C., \& Young, A. (2017). Transformative Leadership in School Counseling: An Emerging Paradigm for Equity and Excellence. Professional School Counseling. https://doi.org/10.1177/2156759X18773581

[59] Singelis, T. M., Triandis, H. C., Bhawuk, D. P. S., \& Gelfand, M. J. (1995). Horizontal and Vertical Dimensions of Individualism and Collectivism: A Theoretical and Measurement Refinement. Cross-Cultural Research, 29(3), 240-275. doi:10.1177/106939719502900302 


\section{GENERAL MANAGEMENT}

[60] Slikkerveer, L. J. (2019). Gotong Royong: An Indigenous Institution of Communality and Mutual Assistance in Indonesia. Integrated Community-Managed Development, 307-320. doi:10.1007/978-3-030-05423-6_14

[61] Suparjo, S. (1970). Islam dan Budaya: Strategi Kultural Walisongo dalam Membangun Masyarakat Muslim Indonesia. KOMUNIKA: Jurnal Dakwah Dan Komunikasi, 2(2), 178-193. doi:10.24090/komunika.v2i2.100

[62] Supriyadi, B., Sudarwanto, B., \& Werdiningsih, H. (2012). In Search of the Power of Javanese Culture against the Cultural Urbanization in Kotagede, Yogyakarta-Indonesia. Procedia Social and Behavioral Sciences, 68, 676-686. doi:10.1016/j.sbspro.2012.12.258

[63] Suwignyo, A. (2019). Gotong royong as social citizenship in Indonesia, 1940s to 1990s. Journal of Southeast Asian Studies, 50(3), 387-408. doi:10.1017/s0022463419000407

[64] Tatum, B. C., Eberlin, R., Kottraba, C., \& Bradberry, T. (2003). Leadership, decision making, and organizational justice. Management Decision, 41(10), 1006-1016. doi:10.1108/00251740310509535
[65] Taufiq, M., . S., \& Widyaningsih, R. (2016). FORMS AND MECHANISMS OF LAW DISPUTE RESOLUTION USING THE PRINCIPLE OF PANCASILA BASED ON LOCAL WISDOM. Jurnal Dinamika Hukum, 16(1). doi:10.20884/1.jdh.2016.16.1.399

[66] Tead, O. (1935). The Art Of Leadership.

[67] Warchulski, D. (2019). Collectivism and Individualism in Language Education. Language and Culture, 215-223. http://hdl.handle.net/10236/00028425

[68] Warrick, D. D. (2017). What leaders need to know about organizational culture. Business Horizons, 60(3), 395-404. doi:10.1016/j.bushor.2017.01.011

[69] Yidong, T., \& Xinxin, L. (2013). How Ethical Leadership Influence Employees' Innovative Work Behavior: A Perspective of Intrinsic Motivation. Journal of Business Ethics. https://doi.org/10.1007/s10551-012-1455-7

[70] Yuristia, A. (2018). Pendidikan sebagai Transformasi Kebudayaan [Education as Cultural Transformation]. Ijtimaiyah Jurnal IImu Sosial Dan Budaya [ljtimaiyah Journal of Social and Cultural Sciences], 2(1). 